\title{
Propose a Model of Urban Landscape Management Deal with City Vandals: A Case Study of $20^{\text {th }}$ District of Tehran
}

\author{
Mohammad Reza Samimi ${ }^{1}$, Hossein Kalantari Khalil Abad $^{2} \&$ Aref Agha Safari ${ }^{3}$ \\ ${ }^{1} \mathrm{PhD}$ student in Urban Planning in Institute of Culture, Art and Architecture (ACECR), Iran \\ ${ }^{2}$ Associate Professor, Department of Architecture and Landscape Research Institute of culture, art\& architecture, \\ Academic Center for Education, Culture \& Research (ACECR), Iran \\ ${ }^{3}$ Assistant Professor of Academic Center for Education, Culture \& Research (ACECR), Iran \\ Correspondence: MohammadReza Samimi, Institute of Culture, Art and Architecture (ACECR), Iran. E-mail: \\ esfehani.mohamad3@gmail.com
}

Received: May 27, 2016

doi:10.5539/mas.v10n12p14
Accepted: June 18, 2016

Online Published: July 11, 2016

URL: http://dx.doi.org/10.5539/mas.v10n12p14

\begin{abstract}
Vandalism is one of the hidden results of the rise of modernism that appearance of this phenomenon can be seen in city centers, schools, sports club, etc. in abundance. And today in urban communities is considered as a serious problem that compromises safety and security of urban communities. Destruction of the urban landscapes by the vandals and loss of interests of citizens in the case of the city face that creates confusion and chaos of urban landscape is not a new problem. And at least in the last three decades considered by the social activist groups and NGOs, environmental scientists, artists, city managers and ordinary people directly and indirectly. It exists convergence and consensus on the desirability of merging the face of the city and reducing urban landscape and urban landscapes as part of a person's identity and is known aspect of human existence. The purpose of this article is providing a model of urban landscape management in dealing with urban vandal from the perspective of residents and administrators. Using existing literature, beginning some management indicators to assess the effects of mining and based on required data were collected through questionnaires from district 20 in Tehran. Study, methods that fits the type of data model is used SWOT and statistical methods to analyze data without parameters. The results show that the effects of vandalism in the considered area were been and can be customized according to the features and functionality and urban potential in this area and by applying strategic planning, according to the aforementioned factors and in the shadow of integrated management sustainable development in order to reduce the effects of destruction in this region. It also seems to be the best kind of theory about urban management in the region, a new theory or system. And in $20^{\text {th }}$ District management model in order to deal with urban vandalism attention to the planners and policy makers in different dimensions is considered. As well as monitoring and planning should be limited to the initial phase and policies But also in the design, implementation and maintenance of urban spaces, urban furniture, etc. should also be considered And in this respect also must be careful.
\end{abstract}

Keywords: Management, Vandalism, Urban landscape, $20^{\text {th }}$ District of Tehran

\section{Introduction}

All societies with different extents in some way involved with aspects of urban vandalism and negative consequences of this damage. Daily life of every citizen in dealing with behavioral manifestations associated vandalistic behaviors. The existence of such a threat to public property in the city, in some form for many citizens is sensible. Guards beings for places such as subways or warnings and signs in public places in order to avoid polluting the environment or to inform the graffiti etc. suggests that these areas coveted by the vandals and their damaging behaviors. All of these behaviors damaging to the institutions of this property and places, that they are responsible for the preparation and maintenance, financial losses and reproduction costs of repair, replacement and cleaning is involved. Including corporate institutions that have entrusted this responsibility at the macro level are municipalities and the organization, acting on behalf of Vandalistic damage and repair costs considerably. In fact, a large part of the increased budget that can be spent on development, construction and beautification of the city, always vandalistic measures to eliminate the offset is assigned. However, the costs that have been created generally compensate by the taxes that will be collected from people. In fact, the people 
indirectly bear the costs of repair and replacement of public facilities. Confusion face of the city and appearing more chaos in the urban order and reduction of the security feeling of the citizens in the wake of a turbulent life in urban space are another dimension of objectivity adverse effects vandalistic measures in urban areas. An example of a survey report states that the destruction of public property in Tehran Costs incurred in 1594 destroyed the public telephone system in 1388, 63.45 billion Rials. According to an official at the telecommunications company on the basis of studies conducted approximately $30 \%$ of the public telephones in the country imposes losses amounting to billions Rials in government spending. He added that every month approximately 8800 damages and 800 cases of theft in connection with public telephones are recorded. (E-books citizenship customs, 2009, p9) To understand the causes of these behaviors can be partially to prevent or control of it. These behaviors may be influenced by another parallel social problem is the feeling of oppression and injustice that sense of deprivation is linked to the problem. That sense of economic deprivation, social and services. Perhaps this dissatisfaction with municipal service delivery with the destruction of public property by citizens as a protest or express their anger with each other. (Mohseni Tabrizi, 1374. 19) $20^{\text {th }}$ District (Rey) is the southernmost urban area in the municipality of Tehran. Due to some factors, such as damaging and abandoned buildings inside the city, narrow streets, Being abandoned of more buildings, long-term buildings damage and ... this area is today one of the most important centers of the incidence of vandalism. That every year causes a lot of damages, including the destruction of public property, destruction of urban furniture, destruction of school property, historic buildings and ... that has hidden and known results and impacts across the $20^{\text {th }}$ District. According to the above explanation this study attempts to determine the different types of economic deprivation, social exclusion and also how much the denial of civil service tends to affect vandalism.

\section{Theoretical Foundations}

Increasing urbanization and urban spaces because of their inherent variability that is associated with, leads to the spread of social harms. Something that has been experienced in many countries. Problems and damage caused by urbanization in the developing countries of much higher dimension and the thriving cities of these countries the problem is more severe. (Ghaqeleh, Kalhor, 1389, 15) On the other hand machine civilization that followed today by development of industrial cities densely populated neighborhoods, lifestyle changes, weakening social cohesion, failures and hidden psychological complexes and suppressed desires and failed aspirations and exacerbate feelings of helplessness, frustration,, disability and abuse is brought, has other consequences. And the growing rebellion of people, especially the younger generation against repressive social realities and external forces. In cities due to population density, moral density, different cultures, values diversity, competition, individualism and collective morale and cohesion to overcome the mechanical and organic solidarity, separation, alienation, diversion and isolation of the individual from society and societal norms manifesting anomic conditions over the rural areas is evident. The existence of informal settlements in the towns borders, dark streets and under bridges, streets and squares geometric shapes, ways unauthorized access to highways, tall buildings and high density too, are abandoned half-built buildings and dilapidated, uncontrolled urban development, including the causes of crime today. (Abdullah Puri, 1390, 5)

At the societal level in the form of mass opposition protests and riots occur and such behavior when they became the characters, creates vandalism and related human damages. Vandalism is one of the hidden results of the rise of modernism that appearance of this phenomenon can be seen in city centers, schools, sports club, etc. in abundance. And today in urban communities is considered as a serious problem that compromises safety and security of urban communities. Flacks (Flacks, 7, 1971) Depending on the application and purpose of the classification of different types Vandalistic behavior can be based on location (city, village, forest, etc.), scope (cultural, political, ...) combined agents (individual or collective), motivated action (entertainment, protest, approved the acquisition in the group) and other aspects divided. Criminological research into vandalism has found that it serves many purposes for those who engage in it and stems from a variety of motives. Sociologist Stanley Cohen describes six different types of vandalism:

1. Acquisitive vandalism (looting and petty theft).

2. Tactical vandalism (to advance some end other than acquiring money or property - such as breaking a window to be arrested and get a bed for the night in a police cell).

3. Ideological vandalism (carried out to further an explicit ideological cause or deliver a message).

4. Vindictive vandalism (for revenge).

5. Play vandalism (damage resulting from children's games).

6. Malicious vandalism (damage caused by a violent outpouring of diffuse frustration and rage that often 
occurs in public settings).

From a social perspective vandalism could be classified in five groups: avarice, tactical, avenger, recreation and hostility.

Destruction of the urban landscapes by the vandals and loss of interests of citizens in the case of the city face that creates confusion and chaos of urban landscape is not a new problem. And at least in the last three decades considered by the social activist groups and NGOs, environmental scientists, artists, city managers and ordinary people directly and indirectly. It exists convergence and consensus on the desirability of merging the face of the city and reducing urban landscape and urban landscapes as part of a person's identity and is known aspect of human existence. According to Prushansky part of the personality of every human being makes his individual identity is the place where he identifies with it and identify the others. In fact, the quality of the physical environment on the quality of work life and social and mental health has a direct effect.

It is suggested that for each of the role-related identities of an individual, there are physical dimensions and characteristics that help to define and are subsumed by that identity. In addition, there is a general place-identity for each individual which reflects his or her unique socialization in the physical world. Review of different doctrines and theories about the environment and landscape shows urban landscape is two-dimensional that its main dimension is human and personal and social behavior in the environment. On this basis we can say environmental and urban space management regardless of behavioral indexes is impossible. Also review of books and comments of masters of urban design and architecture like Lynch, Rappaport and Aplyard and criteria lay down by Ian Bentley and his colleagues can be used as criteria and indexes in order to verify the local identity and sense of belonging of citizens to the places and spaces where considered Criteria such as mean, diversity, richness, personalization capabilities (Sense of belonging) covering a wide range of human relationship with the made environment and according to these criteria are effective in reducing vandals behavior and vandalism. (Municipal monthly magazine, 1383, 11) Paintings exhibited in galleries, ancient furniture and antiques in museums, monuments and religious sites, Statues installed in squares and public places

houses, haunted, parks and public gardens, passages lights, seats for buses and subways, library books, public telephones, urban furniture, spaces and public facilities and bombings aimed at the destruction of public property, destruction of natural persons and legal facilities, destruction of school property, demolition of traffic signs and traffic signs and dozens of other topic of destruction are issues that the damage or failure of them was caused by vandalism and are destroyed. In the meantime, studies and experiences of experts, reflects the importance of the issue of vandalism in various aspects of Iranian society (Mohseni Tabrizi, 1374., 19) Mr. MostafaPour (Director of Studies and Planning Social Affairs and Cultural Center in Tehran) in the first special session entitled "Vandalism in Tehran," said in the last 20 years, maintenance costs of Tehran are 5 trillion Tomans, But now half the cost of Tehran Municipality are maintenance costs that half of this amount will be spent on repairing vandalism damages. However, despite the provision and codification of façade criteria and preparation of design studies and urban landscape of roads and urban spaces in Iranian cities in recent decades, so far indexes and measures of social psychology and human characteristics and behavior of beneficiaries are not emphasized so much in the urban landscape and has been hidden from the eyes of planners and urban designers. In the study of urban landscape design too much emphasis on framework - functional goals and lack of attention to the mental, emotional, cultural and behavior needs of citizens been evident, so that due to the lack of attention to place identities and citizens' fixation, vandal active presence in urban spaces, abnormal social behavior and destruction of urban landscape has been increasing... . Over the years and recent decades Tehran has had staggering growth and the bulk of the immigrants of the country have accumulated in this city. Urban population concentration has led to accumulation and concentration of urban problems. Tehran 20th District is located in the southern part of the metropolitan area, and because some features have been one of the main centers for immigrants that today have the high population density. Today this area is one of the most important centers of the incidence of vandalism. That every year causes a lot of damages, including the destruction of public property, destruction of urban furniture, destruction of school property, historic buildings and ... that has hidden and known results and impacts across the. For an instance it affected on the quality of urban life in the $20^{\text {th }}$ District. And an increase in aggression and violence in cities not only in effective in low working efficiency and general use the studied area, even affect in the increasing of fear feeling and unrest and abnormalities. In this area there are the same and indigenous social structure, the structure of the old worn, population density and moral density, some different cultures, deviation and separation from society that different economic classes are located. Due to the different characteristics of social and economic in region of "Shahr-e- Ray" and existence of new and old natural - historical spaces and views in this region and also seeing the effects of vandalism in the face and body of roads and buildings, this area can be a good case study for study and research on urban management, urban 
landscape against the vandals, so that we can extend these studies to other parts of Tehran. This study tries to answer these questions by conducting a systematic review and precise and finally propose a model of efficient management of the urban landscape.

\section{Research Method}

This research in terms of target is an applied research group, the methodology based on the explanation - survey and includes a two-stage survey to examine and describe the documents and analysis.

In the first stage with the help of library studies and documents, the theoretical framework and the hypotheses have been prepared and in order to assess (accept or reject) the hypothesis with the help of survey and analytical methods of determination (experimental) they are tested. Explanatory method refers to methods and studies seeking to find cause and effect relationships between different variables. In the relational hypothesis the independent variable (x) is usually one of the causes of the characteristics of the dependent variable (y). In this study, data collection is done using field methods, library, questionnaires and interviews with people and related officials. For this purpose, direct referring to statistical and using the information of cities, comprehensive information for the study was provided and then completed through questionnaires, interviews and field studies mentioned. According to the purpose of the study in case of urban management model against city vandals, $20^{\text {th }}$ District in Tehran, statistical society includes citizens, vandals and managers. Since the statistical society in this study, is $20^{\text {th }}$ District in Tehran urban residents, managers (16-24 years) are as the studied population. For urban residents (16-24 years) using the Cochran formula was conducted to determine the sample size. Therefore the numbers of citizens in the $20^{\text {th }}$ District, 382 civilians have been obtained. Because the number of vandal was not identified in the studied area, adjustment formula was used to determine the sample size. As a result, 322 people were identified as resident sample size. For city managers, due to the limited number of them, used the method of referendum. In this study, to analyze the data, SPSS software and statistical methods including correlation test, Chi-square and SWOT analysis model are used.

\section{The Studied Area}

Tehran $20^{\text {th }}$ District is limited from north to Azadegan Highway and $16^{\text {th }}$ District, from west to BeheshtZahra (the main cemetery of Tehran) and $19^{\text {th }}$ District, from east to DolatAbad St, Bibi Shahrbanu Mt, and TaghiAbad road and $15^{\text {th }}$ District, from south to south villages and territory of "Shahr-e-Rey". This area is located about 1,050 meters above sea level, and passes it Darabad, Darband, Tochal and Sorkhehesar rivers. Based on the new division of Tehran Municipality, Tehran Metropolis is divided into 374 neighborhoods. Meanwile $20^{\text {th }}$ District, has 21 neighborhoods. This area encompasses ancient city of Rey that the origin of one of the earliest origins of civilization in Iran near Cheshmeh-Ali's resignation. $20^{\text {th }}$ District (Rey) is the most southern urban area of Tehran Municipality. The criterion action surface of Municipality is 2264 hectares. Rey weather is mild and dry. Within $20^{\text {th }}$ District up to 2394.3 hectares, a wide range of territory (over $25 \%$ ) is residential zone. Although most residential applications located in residential zone but, in the mixed zone, the activities of the conservation and only residential are deployed. The vastitude of residential use in the region is 622 hectares which a large part of it (along with the road network and services) is located in a residential zone 


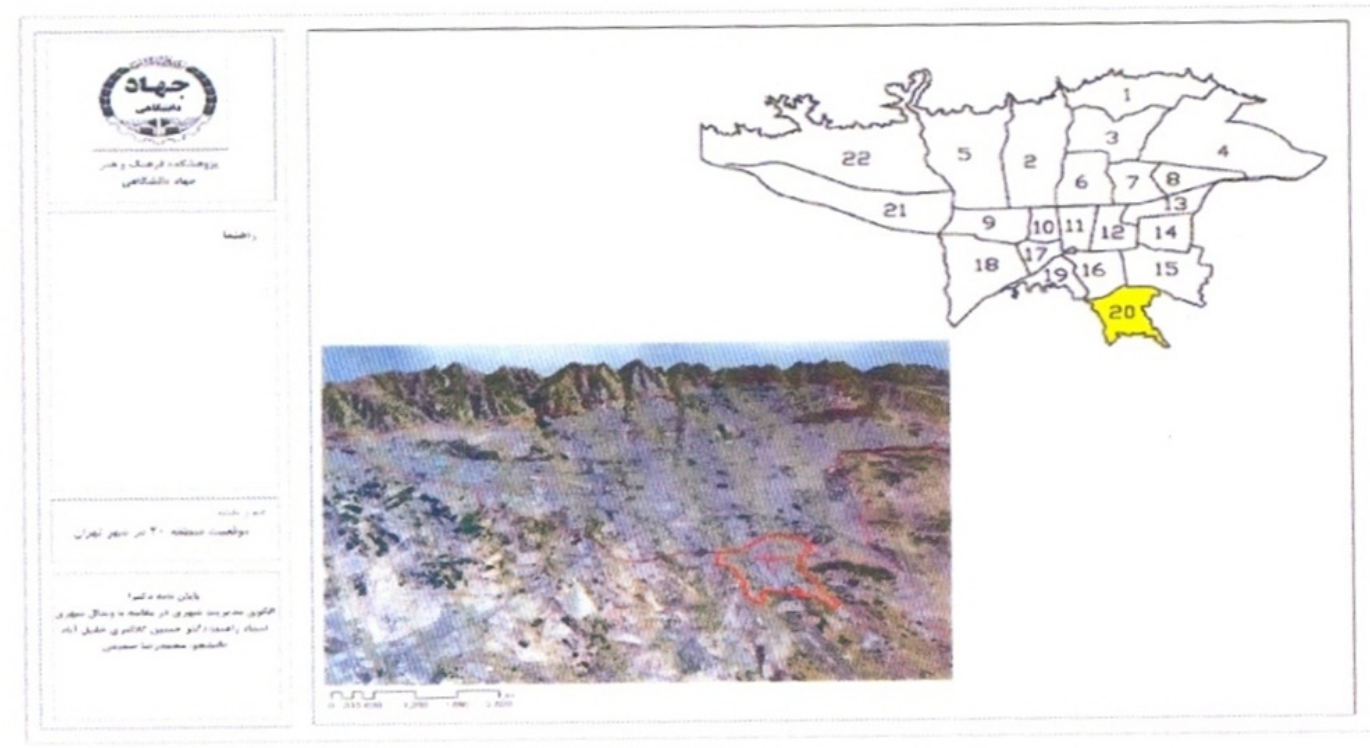

Figure 1. Location of 20th District in Tehran

In 1390 , the population of $20^{\text {th }}$ District based on stats of the Statistical Center of Iran was the equivalent of 340,861 people. The average household size of mentioned district is equal to 3.3 people in the same year and the ratio of 14-year old population to the total population is equal to 2.35 percent. The sex ratio (number of males to females) in the region is equal to 1.03 that this figure is lower than the sex ratio of the city (1.04) About 58.7 percent of the population in this region are married that is more than the average of the city (57.2). In this region dependency rate (the ratio of employed people to the total population) is equivalent to 3.26 persons and it's more than the 2.96 dependency rate in the city. Illiteracy rate in the region is 9.6 percent more than the rate of illiteracy in the city (6 percent). During the ten-year period from 1375 to 1385 , about 9.6 percent of residents have entered the neighborhood. The unemployment rate in the region $(8.3 \%)$ and higher than the city (7.5 percent) The percentage of the active population in the region is about $83.3 \%$ less than the percentage of active population (about 41.5 percent). 7 -fold classification of spatial organization and typology of functional structure in $20^{\text {th }}$ District has been proposed. It should be noted that the boundaries of these lines matches with regional and national documents identified areas detailed plan. The above-mentioned categories are as follows: 1. the old buildings 2.construction industry 3.historic - religious buildings4.green space 5.Passages 6.agricultural structure 7.residential buildings

According to the Supreme Council for Planning Architecture a surface equivalent to 98 hectares of old buildings (third kind) three conditions are throughout $20^{\text {th }}$ District that need urgent and immediate intervention. On the other hand, based on studies other problematic and old constructions in addition to 98 hectares in this area are as follows:

1.Old and organic buildings in the area around the shrine of Hazrat AbdulAzim (AS) in the space of 144 hectares that some parts of it have been identified in the map of Supreme Council for Planning and Architecture.

2. Old, problematic, residential and manufactory buildings is located near the historical and valuable area in Cheshmeh Ali and Tuqrul Tower in the space of 91 hectares that this area has also part of the old buildings that have been identified in the map of Supreme Council

3. Old and problematic construction (workshop and industrial) in the northwest and the Javanmard Ghasab Alley in 231 hectares area. The map of Supreme Council only small parts of Javanmard Ghasab Alley has been identified. However, in the industrial area at the north of this region due to the lack of residential areas, it does not exist any aging buildings in the map of Supreme Council. While the industrial area to in north of this region is one of the very old buildings and structures within the area is abandoned, Moreover, it has much potential to develop the area south of Tehran. Among the main characteristics of these constructions in the urban vandalism can be contributed to the following items:

1- Monuments destroyed and abandoned inside the region.

2- Narrow streets, more abandoned buildings, long-term damage of buildings to the facial tissue. Industrial and 
workshop in texture with an area of 489 hectares Rey range is included.

Industrial and manufactory buildings in Shahr-e-Rey is an area about 489 hectares. This area is in the north and DolatAbad District and West Shahid Rajai Blvd and parts of the neighborhood Alaeen on the highway Tehran Varamin. Concentration of industrial activities, car repair, etc. in the area of the salient features of the studied area. In the historical - religious region existence of Abdul-Azim shrine (AS) as well as monuments such as Tugrul Tower, Cheshme-Ali and the tomb of Ibn Babawayh has Outstanding

Tourism Property. According to this historical - tourism of this region with an area of over 230 hectares is spread around historical monuments. Green spaces with a total area of 250 hectares mainly in the northwest and northeast parts of their range. Existence of sports and recreational spaces in regional parks has increased the boom and population of these spaces. Now one of the issues that can affect an increased incidence of vandalism in these spaces can be mentioned the following:

1- Lack of proper lighting at night

2- Creating a cozy and quiet corners in the parks

The passages in this report are first-degree commercial and arterial streets. This range is in the centrality of Shahr-e- Rey Sq and streets and Fedayeen Islam St, Zakariya Razi St and also encompasses Ibn Babawayh. In fact, this range is also the communication route between the city's historic cores. Existence of commercial spaces, pedestrian presence in these spaces during the day and lack of social supervision at night due to the closure of shops is characteristic of this region. Mainly agricultural land in $20^{\text {th }}$ District and the neighborhood of Estakhr and Nafarabad are located in the southern area. There are barren lands and abandoned at the edge of the area that is considered as a property. About 1,000 hectares from construction dedicated to residential construction. The construction boom in the region and increasing building density in recent years has added to the population of the region. According to the detailed plan

there are sufficient per capita services at a local level that is one of the strengths of the residential construction. The important point in relation to this building in the neighborhood with green spaces and industrial area that due to inadequate public supervision for the construction of residential buildings, as well as vandalism and destruction oriented perspective is influenced.

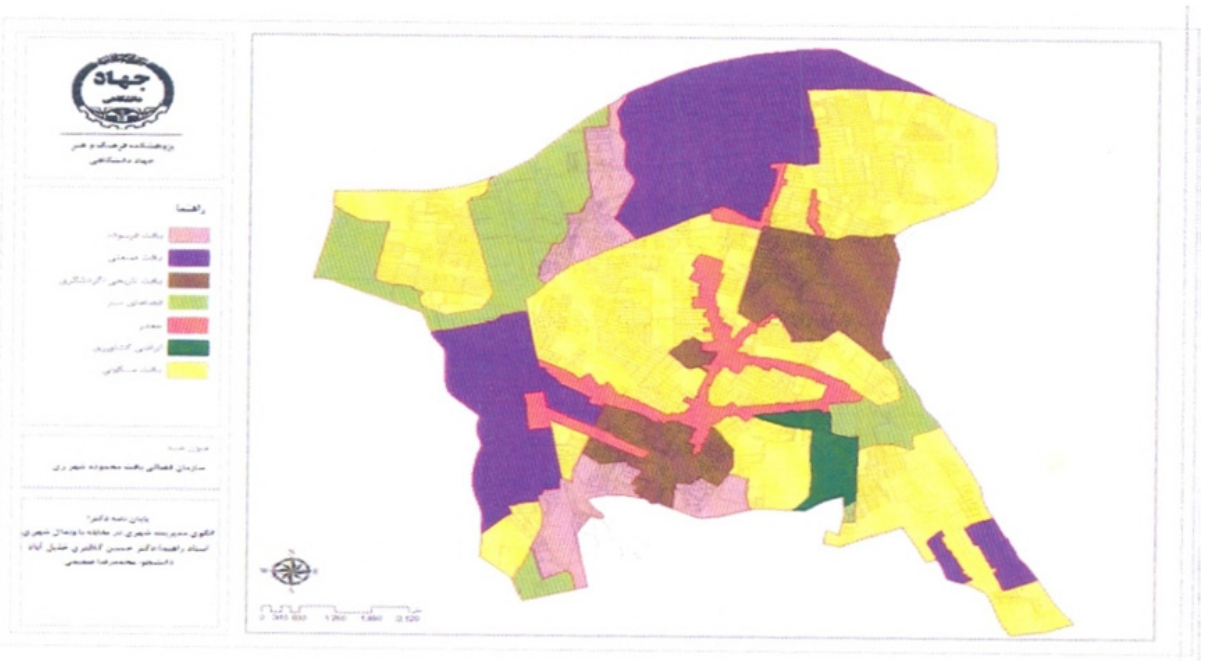

Figure 2. Spatial Organization of the study area

\section{Evaluation of Vandalism in the $20^{\text {th }}$ District}

According to field observations were made, it can be concluded that recreational and avarice vandalism is the most cases of vandalism are identified in Rey. Vandalism variety gathered in the following table is presented for different seven regions of Shahr-e-Rey Space Agency.

Table 1. Percentage of vandalism gathered in regions of Rey Space Agency

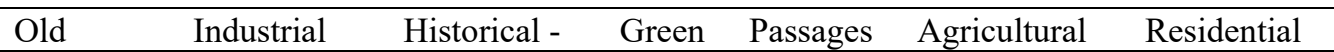




\begin{tabular}{cccccccc}
\hline & Construction & Construction & $\begin{array}{c}\text { Religious } \\
\text { Construction }\end{array}$ & Spaces & & Construction & Construction \\
\hline $\begin{array}{c}\text { Acquisitive } \\
\text { vandalism }\end{array}$ & 10 & 75 & 25 & 15 & 10 & 0 & 10 \\
tactical & 10 & 5 & 15 & 25 & 15 & 0 & 5 \\
$\begin{array}{c}\text { vandalism } \\
\text { Vindictive }\end{array}$ & 20 & 0 & 5 & 15 & 30 & 0 & 20 \\
$\begin{array}{c}\text { vandalism } \\
\quad \begin{array}{c}\text { Play } \\
\text { vandalism }\end{array}\end{array}$ & 25 & 15 & 15 & 25 & 15 & 0 & 30 \\
$\begin{array}{c}\text { Ideological } \\
\text { vandalism }\end{array}$ & 35 & 5 & 40 & 20 & 30 & 0 & 35 \\
\hline
\end{tabular}

Source: Field collecting

According to the researches and, as the map shows the number 4, the most vandalism occurs in the residential constructions, outdoors and industrial constructions. Acquisitive vandalism usually occurs in the industrial constructions. According to the conclusion of researcher and experts' view, The reason for this is unrelated to the lack of social control spaces, especially at night, and the lack of a sense of belonging from tradesmen and employees in this area to their business environment. Also in residential construction and green spaces, play vandalism has a high percentage. At first glance, this phenomenon can be regarded to the presence of young people in these areas and the need for recreational and energizing activities. Because

this opportunity based on sports and recreational capita in the area is low and especially in the old construction and the lack of perspective in these areas per capita can be seen in vandalism and appearance of per capita deficit can be seen in these regions from vandalism view. In the following showed dominant vandalism map in each of the seven areas of Space Agency. As it is obvious on the map, ideological vandalism, play vandalism and acquisitive vandalism are the highest density and the percentage of replicates in Rey.

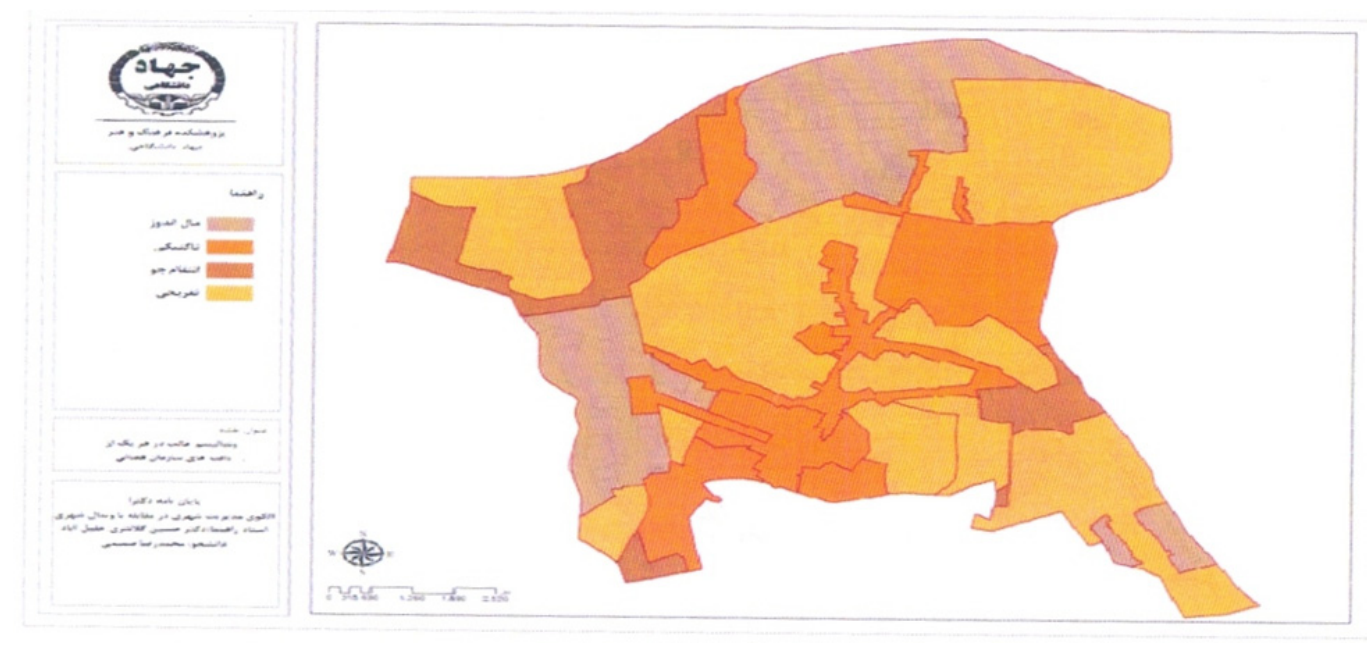

Figure 3. The distribution of vandalism in $20^{\text {th }}$ District

As shown in Figure 3 play and ideological vandalism have high percentage of building in $20^{\text {th }}$ District. In fact, the main problem in residential and history - tourism buildings and green spaces of in vandalism view is play or ideological vandalism and sometimes acquisitive vandalism. The map indicates that as much as we move from the residential area to the industrial area, in fact we move from vandalism diversity and the birth of vandalism view toward avarice and vindictive vandalism and the statistics this type of urban vandalism increases. Following the distribution map of vandalism seen in $20^{\text {th }}$ District are presented. In this map, based on the vandalism number of each quintuplet groups (acquisitive, play, ideological, vindictive and tactical vandalism) cases have been recorded and is formulated in the form on below map. As is clear in Figure 4 vandalism statistics in the residential buildings and green space area is higher than in other spaces. Also, the minimum vandalism statistics is owned agricultural land and its surrounding area. It can be attributed to a lack of grounds for acts of vandalism, because of lack of urban walls and the lack of urban furniture in this area not provided enough time to vandalistic acts. 


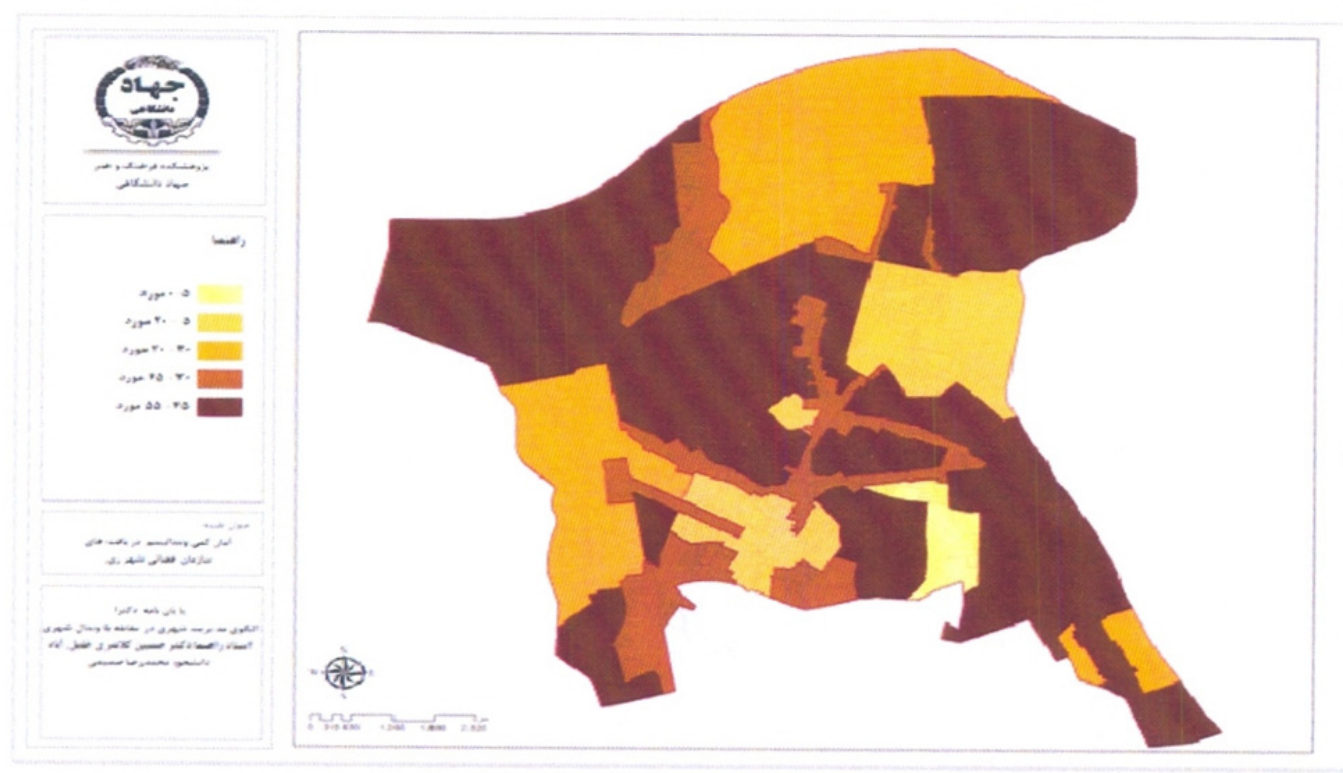

Figure 4. Map of vandalism observed in 20th District

According to maps of the spatial structure as well as the dominant type of vandalism in each of the areas and buildings identified in 20th District

The results can be derived from these maps are analyzed and presented in the following field observations. Monitoring of community and a sense of belonging in the environment has a direct correlation with the incidence of vandalism. Depending on the prevalent type of vandalism in the industrial area that is vandalism of avarice, compared to common recreation vandalism in the old and residential construction, it can be concluded that if the sense of belonging to the building and also social control over urban spaces increase, will influence to vandalistic actions and leads them from vandalism avarice to ideological and recreation vandalism. The level of social control in urban areas

directly linked to decreasing the amount of vandalism. According to the rate of vandalism in the historical tourism and residential area than vandalism rates in industrial areas it can be stated if the level of social control in urban areas increased, the rate of vandalistic actions may decrease

There is a reverse relationship between the quality of construction and the repetition of vandalistic acts. In other words, as the quality of urban spaces better and aesthetically is more desirable, vandalistic acts will be seen less. By comparing the abandoned spaces inside the old buildings and new residential areas in the studied area, it can be concluded spaces that had the lowest level of quality of have had a greater number of vandalistic acts. As well as the spaces with appropriate urban furniture and higher quality had less vandalism

With regard to the comparison of residential areas with each other it seems that there is indirect proportion between economic level of resident families and the price of land against urban vandalism. In fact, with increasing economic status of urban households, there are fewer vandalistic actions in the area of household's residence

Indirect ratio between the quality of the buildings built and urban vandalism in urban area are in the $20^{\text {th }}$ District. In fact, in the old empty buildings,

there are abandoned spaces and dilapidated buildings. These spaces and buildings are suitable place for vandalistic acts such as graffiti, fires, collecting garbage and.... While in these regions, areas that are more appropriate in natural status, there is less vandalistic acts.

\section{The Results and Consequences}

In order to present the pattern of the city view against vandalism: case study: $20^{\text {th }}$ District of Tehran

Studying the 4 factors (SWOT) in reducing problems and improving the situation is necessary. After studying the $20^{\text {th }}$ District of Tehran and getting people's ideas, the following has been made. According to the questionnaires these solutions are presented: first the inner and outer items have been studied through SWOT and then people's opinion are presented. Via people's ideas and city management these findings are shown on social financial cultural and management point of view. These are as shown beneath according to the reduction of vandals: 
Table 2. Matrix of outer factors on financial cultural social points of view on vandalism in the $20^{\text {th }}$ area of Tehran

\begin{tabular}{|c|c|c|}
\hline & Opportunity & threats \\
\hline $\begin{array}{l}\text { Social, } \\
\text { populational } \\
\text { and cultural }\end{array}$ & $\begin{array}{l}\text { - informing through banners (professional } \\
\text { judgment) } \\
\text { - } \text {-reinforcement of the women`s role in local } \\
\text { management } \\
\text { - } \text {-tourism through establishing new tourist centers } \\
\text { - } \text {-presenting the cultural religious historical items } \\
\text { on the area }\end{array}$ & $\begin{array}{l}\text { - large areas of waste land and } \\
\text { isolated zones and run down } \\
\text { buildings } \\
\text { - -low budget } \\
\text { - } \text {-destroying cultural places } \\
\text { because of lack of attention } \\
\text { - } \text {-gap of social classes }\end{array}$ \\
\hline Fin & $\begin{array}{l}\text { - Increasing the potentiality of tourism for } \\
\text { historical and cultural and religious places } \\
\text { - Increasing employment }\end{array}$ & $\begin{array}{l}\text { - Unwillingness of investors } \\
\text { because of the plan for } \\
\text { developing the holy shrine }\end{array}$ \\
\hline Fra & $\begin{array}{l}\text { - Using the private investors in construction plans } \\
\text { - Absorbing government credit in improving the } \\
\text { area } \\
\text { - } \text { Tourism in Rey } \\
\text { - Attracting investment in the area around the holy } \\
\text { shrine } \\
\text { Making the shrine and bazaar in the core of the } \\
\text { city }\end{array}$ & $\begin{array}{l}\text { - Destroying the gardens and } \\
\text { sceneries and agricultural fields } \\
\text { - Mafia in construction programs } \\
\text { - Increase of the migration of } \\
\text { people to the area and dwelling in } \\
\text { rundown buildings }\end{array}$ \\
\hline Man & $\begin{array}{l}\text { - } \quad \text { Improving the city standards can help poverty } \\
\text { - } \quad \text { Using people help } \\
\text { - } \quad \text { Using public places for religious purposes }\end{array}$ & $\begin{array}{ll}\text { - } & \text { Slum dog as lack of observing } \\
\text { - } & \text { Afghan immigration } \\
\text { - } & \text { Constructing substandard } \\
& \text { buildings }\end{array}$ \\
\hline
\end{tabular}

Table 3. Matrix of inner factors on financial cultural social points of view on vandalism in the $20^{\text {th }}$ area of Tehran

\begin{tabular}{|c|c|c|}
\hline & Strengths & Weakness \\
\hline $\begin{array}{l}\text { Social, populational } \\
\text { and cultural }\end{array}$ & $\begin{array}{l}\text { - Special value of Rey as Tehran`s cultural } \\
\text { and religious center } \\
\text { - High percentage of educated people in } 1390 \\
\text { - Young habitat } \\
\text { - Living different classes in the same place } \\
\text { - NGOs } \\
\text { - Council centers in all parts }\end{array}$ & $\begin{array}{l}\text { - Bad designing of the buildings } \\
\text { - Vandalism } \\
\text { - Crime } \\
\text { - Criminals in public places like parks } \\
\text { - No attention to historical places }\end{array}$ \\
\hline Finan & $\begin{array}{l}\text { - Shrine as absorbing investment } \\
\text { - Young habitat } \\
\text { - Reasonable expenses for most families } \\
\text { - Low prices for houses down of the town } \\
\text { - Small buildings } \\
\text { - Location of shrine in the south of the area } \\
\text { - Bazaars } \\
\text { - Agriculture business and tourism } \\
\text { - Cheap land and houses } \\
\text { - Bazaars }\end{array}$ & $\begin{array}{l}\text { - Middle and low class } \\
\text { - Low salaries } \\
\text { - Families under the poverty line } \\
\text { - No balance in prices in different areas } \\
\text { - Municipal meddling in trading houses } \\
\text { - Salesmen on holidays } \\
\text { - Low job vacancies }\end{array}$ \\
\hline Framework & $\begin{array}{l}\text { - Isolated and waste lands } \\
\text { - Business and service } \\
\text { - Constructing Apartments } \\
\text { - Shrine as the core } \\
\text { - Shrine as locating } \\
\text { - Historical places } \\
\text { - Greeneries }\end{array}$ & $\begin{array}{l}\text { - Lack of interaction } \\
\text { - The unsuitable buildings } \\
\text { - Lack of order in city planning } \\
\text { - High and unsuitable buildings } \\
\text { - Impractical high buildings } \\
\text { - Highways } \\
\text { - Different forms of building in the } \\
\text { zone }\end{array}$ \\
\hline Management & - Urban infrastructure managers pay attention & - The number of public transport in \\
\hline
\end{tabular}


to passages in the proposals (Officials questionnaire)

- The cost of public transport in "Ray" is relatively good (questionnaire) terms of most residents is not enough

(General questionnaire)

- Most of the residents of these neighborhoods are low-income urban poverty line

(One million and 200 thousand Tomans)

(The questionnaire and documents)

Based on this analysis, can be proposed a the following as the most important challenges of urban management in " $20^{\text {th }}$ District of Tehran" in dealing with different aspects of urban vandalism:

- $\quad$ Failure of crisis management

- The presence of disabled and weak people in urban spaces

- Lack of services and comforts

- Irregularities in the maintenance and operation of urban public elements such as natural areas, historic buildings, public spaces

- Incorrect locating urban buildings and indiscipline in development

- Incorrect use and maintenance of urban furniture

- Low quality programs, services and urban constructions

- Lack of attention and repair of damaged urban furniture

According to the analysis presented and the viewpoints of the inhabitants of " $20^{\text {th }}$ District ",it can said that influencing factors and indexes of recommended strategies for each part of research summarized and proposed as follows.

Table 4. Suggested solutions

\begin{tabular}{|c|c|c|}
\hline $\begin{array}{l}\text { Suggested } \\
\text { solutions }\end{array}$ & Citizens & Managers \\
\hline $\begin{array}{l}\text { Social } \\
\text { Solutions }\end{array}$ & $\begin{array}{l}\text {-Increasing social counseling centers in neighborhoods } \\
\text { and schools for counseling and psychotherapy of children } \\
\text { - Paying attention to the education, culture and } \\
\text { propaganda on the subject of vandalism, such as making } \\
\text { cartoon programs to educate children at early ages } \\
\text { - creating grounds for public participation in community } \\
\text { issues by providing correlation between officials and } \\
\text { people } \\
\text {-paying attention to quality of life, social equitable } \\
\text { distribution of income, wealth and facilities, } \\
\text {-Paying attention to the effect of constructions of the city } \\
\text { in personal and social behavior } \\
\text { - Increasing the participation and social responsibility } \\
\text {-propaganda through the media } \\
\text {-internalizing the culture of citizenship } \\
\text {-improving urban living standards } \\
\text {-creating public trust and confidence of the activities } \\
\text { of authorities }\end{array}$ & $\begin{array}{l}\text { - Increasing sense of } \\
\text { collectivism through increasing } \\
\text { dialogue and partnership } \\
\text { - Increasing environmental } \\
\text { awareness } \\
\text { - Creating incentives through } \\
\text { environmental and physical } \\
\text { stimuli } \\
\text { - Increasing public scrutiny. } \\
\text {-spatial quality of urban facilities } \\
\text { - increasing quality of housing in } \\
\text { the city } \\
\text {-Creating culture of citizenship }\end{array}$ \\
\hline
\end{tabular}


- increasing public surveillance as a deterrent to prevent

crime

\begin{tabular}{|c|c|c|}
\hline $\begin{array}{l}\text { Designed \& } \\
\text { Framework }\end{array}$ & $\begin{array}{l}\text { - considering the strength and physical form suitable for } \\
\text { the constructions }\end{array}$ & $\begin{array}{l}\text { - Attractive design and artistic } \\
\text { urban furniture }\end{array}$ \\
\hline Solutions & $\begin{array}{l}\text { - Paying attention to the aesthetics in the construction of } \\
\text { property and construction of facilities } \\
\text { - Removing high-risk areas and abandoned parking } \\
\text { - Avoiding isolation and separation in buildings } \\
\text { - correct alignment of buildings next to each other and the } \\
\text { use of appropriate materials } \\
\text { - improving the restoration and maintenance of buildings } \\
\text { - Designing and creating urban spaces that make the } \\
\text { citizens be active } \\
\text { - observing principles that beautify the city in its various } \\
\text { dimensions such as buildings, streets, gardens, etc }\end{array}$ & $\begin{array}{l}\text { - locating urban furniture so that } \\
\text { productive social activities in } \\
\text { space take place } \\
\text {-Becoming aware of the } \\
\text { functioning of urban furniture } \\
\text { designer in urban areas } \\
\text { - Designing and implementing } \\
\text { appropriate places to sit in the } \\
\text { open residential areas } \\
\text {-readability and compatibility } \\
\text { with the environment and urban } \\
\text { furniture } \\
\text { - regulating usable urban land } \\
\text { patterns } \\
\text {-careful selection of appropriate } \\
\text { equipment in order to lower } \\
\text { vandals }\end{array}$ \\
\hline $\begin{array}{l}\text { Management } \\
\text { Solutions }\end{array}$ & $\begin{array}{l}\text {-Understanding the causes and roots of destructive } \\
\text { behavior and developing a plan and strategy to fix them } \\
\text {-increasing social security } \\
\text {-enactment of appropriate legislation for social security } \\
\text { and support all aspects of the venerable people } \\
\text { - Developing a lessons, and training to avoid vandalism } \\
\text { - management planning to design and locate equipment } \\
\text { and facilities }\end{array}$ & $\begin{array}{l}\text { - aligning educational } \\
\text { institutions, cultural, religious, } \\
\text { media and above all the family } \\
\text { with urban management } \\
\text { - Understanding the causes and } \\
\text { roots of destructive actions and } \\
\text { define strategies to overcome } \\
\text { them } \\
\text { - improving urban living } \\
\text { standards in all areas specially in } \\
\text { poor regions and localities. } \\
\text { - providing the necessary } \\
\text { training classes and different } \\
\text { groups of city } \\
\text { - Planning to motivate public } \\
\text { participation in municipal } \\
\text { activities } \\
\text { - familiarizing the citizens with } \\
\text { the essentials of urban life } \\
\text { - beautification of the city } \\
\text { - Creating cultural and social } \\
\text { trust }\end{array}$ \\
\hline
\end{tabular}




\begin{tabular}{|c|c|c|}
\hline & & $\begin{array}{l}\text { - Eliminating signs of } \\
\text { discrimination in different areas } \\
\text { of the city }\end{array}$ \\
\hline $\begin{array}{l}\text { Economic } \\
\text { solutions }\end{array}$ & $\begin{array}{l}\text { - providing employment opportunities for youth within } \\
\text { the area } \\
\text { - Arranging disturb and disorient jobs } \\
\text { - rehabilitate abandoned land around the Rey market }\end{array}$ & $\begin{array}{l}\text { - strengthening domestic } \\
\text { businesses and crafts in the area } \\
\text { - Creating and supporting } \\
\text { self-employment markets } \\
\text { - Supporting public institutions } \\
\text { of self-employment }\end{array}$ \\
\hline
\end{tabular}

According to the proposals in the field of urban management in different dimensions and using SWOT analysis is tried to provide priority and optimized strategies in different dimensions. For this purpose, using SWOT analysis on different aspects of the strategy is provided. It should be noted in order to provide optimal strategy In addition to considering the views of the people and officials SWOT table parameters in each dimension is concerned. In order to prioritize strategies and to obtain optimal strategies in each dimension of the design and planning action is strategic evaluation using Qspm techniques. In this method, Internal and external environment of studied area in each of the social, economic, framework and management aspects, is examined. As a result of the 4 strategies presented in the SWOT matrix (offensive, defensive, compliance and contingency Strategy) strategic priority will be identified in any dimension.

In this part internal and external factors which is obtained from the social dimension is evaluated in table .....

Table 5. The evaluation of internal factors in social field

\begin{tabular}{|c|c|c|c|c|}
\hline \multicolumn{2}{|c|}{ Internal factors } & \multirow{2}{*}{$\begin{array}{l}\text { Normalized } \\
\text { Coefficient } \\
0.08\end{array}$} & \multirow{2}{*}{$\begin{array}{l}\text { Score } \\
4\end{array}$} & \multirow{2}{*}{$\begin{array}{l}\text { Weighted } \\
\text { Score } \\
0.32\end{array}$} \\
\hline \multirow[t]{6}{*}{ Strengths } & Rey historical and religious status as the center of Tehran & & & \\
\hline & $\begin{array}{l}\text { Rey high percentage of literacy rate in } 2011 \text { ( } 86.5 \text { percent) } \\
\text { (National Documents) }\end{array}$ & 0.06 & 3 & 0.18 \\
\hline & $\begin{array}{l}\text { Presence of young people in the region (national documents } \\
\text { and field observations) }\end{array}$ & 0.08 & 4 & 0.32 \\
\hline & $\begin{array}{l}\text { The coexistence of different income groups and classes } \\
\text { together (field observations) }\end{array}$ & 0.09 & 4 & 0.36 \\
\hline & $\begin{array}{l}\text { Public institutions such as young intellectuals, donors, and ... } \\
\text { (interviews with authorities) }\end{array}$ & 0.08 & 3 & 0.24 \\
\hline & local councils in all neighborhoods (field observations) & 0.06 & 4 & 0.24 \\
\hline \multirow[t]{7}{*}{ Weaknesses } & $\begin{array}{l}\text { Anonymous furnished quarters and poor design of urban } \\
\text { furniture }\end{array}$ & 0.07 & 2 & 0.14 \\
\hline & $\begin{array}{l}\text { Noticing the education, culture and propaganda, on the } \\
\text { subject of vandalism }\end{array}$ & 0.08 & 1 & 0.08 \\
\hline & $\begin{array}{l}\text { Crime and insecurity due to poor brightness of passages (field } \\
\text { observations) }\end{array}$ & 0.10 & 2 & 0.20 \\
\hline & $\begin{array}{l}\text { The presence of thugs at the local level, especially in the } \\
\text { parks of the neighborhoods }\end{array}$ & 0.09 & 2 & 0.18 \\
\hline & The absence of controller in open spaces & 0.07 & 1 & 0.07 \\
\hline & The lack of identity and intimacy in urban areas & 0.08 & 2 & 0.16 \\
\hline & Not Paying attention to the historical identity of & 0.06 & 2 & 0.12 \\
\hline
\end{tabular}


neighborhoods

\begin{tabular}{lll}
\hline Total & 1.00 & 2.61 \\
\hline
\end{tabular}

Table 6. Evaluation of external factors in social field

\begin{tabular}{|c|c|c|c|}
\hline External factors & $\begin{array}{l}\text { Normalized } \\
\text { Coefficient }\end{array}$ & Score & $\begin{array}{l}\text { Weighted } \\
\text { Score }\end{array}$ \\
\hline Notification of urban actions through banners (professional judgment) & 0.12 & 4.00 & 0.48 \\
\hline $\begin{array}{l}\text { Strengthening the role of women in management of areas } \\
\text { (professional judgment) }\end{array}$ & 0.10 & 3.00 & 0.30 \\
\hline Strengthening the identity of residential neighborhoods & 0.13 & 4.00 & 0.52 \\
\hline $\begin{array}{l}\text { Potential for development of tourism and pilgrimage tourism through } \\
\text { the establishment of new centers with the available resources } \\
\text { (professional judgment) }\end{array}$ & 0.13 & 4.00 & 0.52 \\
\hline $\begin{array}{l}\text { Renewing the identity of area due to historical, cultural and religious } \\
\text { characteristics }\end{array}$ & 0.11 & 4.00 & 0.44 \\
\hline Lands in the margins and the city & 0.09 & 2.00 & 0.18 \\
\hline Non-financial investment in the range of peripheral areas & 0.10 & 1.00 & 0.10 \\
\hline The loss of spaces with identity and history as a result of neglect & 0.10 & 2.00 & 0.20 \\
\hline Intensified urban inequality in the region. & 0.12 & 2.00 & 0.24 \\
\hline Total & 1.00 & & 2.98 \\
\hline
\end{tabular}

Thus, according to Figure..... priority strategies in social field should be often aggressive strategies

\begin{tabular}{|c|c|c|}
\hline Conservative & & Offensive \\
\hline Defensive & Competitive \\
\hline
\end{tabular}

The economic dimensions of the internal and external factors that are obtained from the evaluation are shown in Table 7.

Table 7. The evaluation of internal factors in economic field

\begin{tabular}{|c|c|c|c|c|}
\hline \multicolumn{2}{|c|}{ Internal factors } & \multirow{2}{*}{$\begin{array}{l}\text { Normalized } \\
\text { Coefficient }\end{array}$} & \multirow{2}{*}{$\begin{array}{l}\text { Score } \\
4\end{array}$} & \multirow{2}{*}{$\begin{array}{l}\text { Weighted } \\
\text { Score } \\
0.40\end{array}$} \\
\hline Strengths & $\begin{array}{l}\text { Shrines to attract population and generate revenue for } \\
\text { the region }\end{array}$ & & & \\
\hline & having a significant young population in the region & 0.07 & 3 & 0.21 \\
\hline & $\begin{array}{l}\text { Consistent income and expenditure for most households } \\
\text { in neighborhoods }\end{array}$ & 0.08 & 4 & 0.32 \\
\hline & $\begin{array}{l}\text { The relatively low price of housing in the southern } \\
\text { neighborhoods }\end{array}$ & 0.09 & 4 & 0.36 \\
\hline & Abdul Azim shrine in southern part of area & 0.08 & 3 & 0.24 \\
\hline & $\begin{array}{l}\text { traditional and new commercial markets in the West } \\
\text { study area }\end{array}$ & 0.10 & 4 & 0.40 \\
\hline \multirow[t]{6}{*}{ Weaknesses } & $\begin{array}{l}\text { Existing most households below the poverty line } \\
\text { wrapping }\end{array}$ & 0.07 & 3 & 0.21 \\
\hline & Price imbalances between various neighborhoods & 0.08 & 2 & 0.16 \\
\hline & $\begin{array}{l}\text { Municipal involvement in lands NafarAbad } \\
\text { neighborhood and stripping people to buy and sell them } \\
\text { and put them in the municipality authority }\end{array}$ & 0.10 & 2 & 0.20 \\
\hline & Coming vendors on holidays & 0.08 & 2 & 0.16 \\
\hline & Lack of job opportunities & 0.07 & 1 & 0.20 \\
\hline & $\begin{array}{l}\text { The use of trade and agricultural potential and becoming } \\
\text { a tourism region }\end{array}$ & 0.08 & 2 & 0.16 \\
\hline Total & & 1.00 & & 2.89 \\
\hline
\end{tabular}


Table 8. Evaluation of external factors in economic field

\begin{tabular}{|c|c|c|c|}
\hline External factors & $\begin{array}{l}\text { Normalized } \\
\text { Coefficient }\end{array}$ & Score & $\begin{array}{l}\text { Weighted } \\
\text { Score }\end{array}$ \\
\hline $\begin{array}{l}\text { Potential for development of tourism and pilgrims through the } \\
\text { establishment of new centers of tourism using the existing sources }\end{array}$ & 0.25 & 4.00 & 1.00 \\
\hline The development of employment opportunities in the region & 0.20 & 3.00 & 0.60 \\
\hline $\begin{array}{l}\text { Potential for development of tourism and pilgrimage tourism through } \\
\text { the establishment of new centers with the resources available } \\
\text { (professional judgment) }\end{array}$ & 0.25 & 4.00 & 1.00 \\
\hline $\begin{array}{l}\text { The lack of interest by investors to invest in the neighborhood } \\
\text { Nafarabad }\end{array}$ & 0.15 & 2.00 & 0.30 \\
\hline Non-financial investment in the range of peripheral areas & 0.15 & 1.00 & 0.15 \\
\hline Total & 1.00 & & 3.05 \\
\hline
\end{tabular}

Thus, according to Figure..... priority strategies in economic field should be often aggressive strategies

\begin{tabular}{|l|l|l|}
\hline Conservative & & Offensive \\
\hline & & \\
\hline Defensive & Competitive & \\
\hline
\end{tabular}

Table 9. The evaluation of internal factors in framework field

\begin{tabular}{|c|c|c|c|c|}
\hline \multicolumn{2}{|c|}{ Internal factors } & \multirow{2}{*}{$\begin{array}{l}\text { Normalized } \\
\text { Coefficient } \\
0.13\end{array}$} & \multirow{2}{*}{$\begin{array}{l}\text { Score } \\
4\end{array}$} & \multirow{2}{*}{$\begin{array}{l}\text { Weighted } \\
\text { Score } \\
0.52\end{array}$} \\
\hline Strengths & $\begin{array}{l}\text { Establishment of trans-regional and commercial service } \\
\text { around the holy shrine }\end{array}$ & & & \\
\hline & $\begin{array}{l}\text { Strong commercial straight and walking space around } \\
\text { the shrine }\end{array}$ & 0.10 & 4 & 0.40 \\
\hline & $\begin{array}{l}\text { shrine of Hazrat Abdul Azim (AS) as a core indicator } \\
\text { in the region. }\end{array}$ & 0.08 & 4 & 0.32 \\
\hline & Historical monuments & 0.15 & 4 & 0.60 \\
\hline & Having a green and suitable open space & 0.12 & 3 & 0.36 \\
\hline \multirow[t]{5}{*}{ Weaknesses } & Existing open land and in the region & 0.08 & 2 & 0.16 \\
\hline & $\begin{array}{l}\text { Uneven texture and fine-grained, organic network in } \\
\text { the central area and around the shrine }\end{array}$ & 0.10 & 2 & 0.20 \\
\hline & $\begin{array}{l}\text { Distorted appearance of the building, especially in new } \\
\text { residential areas }\end{array}$ & 0.08 & 2 & 0.16 \\
\hline & $\begin{array}{l}\text { Rupture and discontinuity in the structure of open land } \\
\text { and wide crops }\end{array}$ & 0.08 & 2 & 0.16 \\
\hline & $\begin{array}{l}\text { Building density mismatch in various neighborhoods } \\
\text { and the impact on other developed and underdeveloped } \\
\text { areas }\end{array}$ & 0.08 & 2 & 0.16 \\
\hline
\end{tabular}

Table 10. Evaluation of external factors in framework field

\begin{tabular}{clccc}
\hline \multicolumn{1}{c}{ External factors } & $\begin{array}{c}\text { Normalized } \\
\text { Coefficient }\end{array}$ & $\begin{array}{c}\text { Score } \\
\text { Opportunity }\end{array}$ & $\begin{array}{c}\text { Weighted } \\
\text { Score }\end{array}$ \\
& $\begin{array}{l}\text { Ability to attract tourists and improve the image of } \\
\text { government funds in the body of the organization }\end{array}$ & 0.25 & 4.00 & 1.00 \\
& $\begin{array}{l}\text { Organizing worn out texture } \\
\text { The possibility of equipping urban spaces to urban }\end{array}$ & 0.20 & 3.00 & 0.60 \\
& furniture robust and elegant design & 4.00 & 1.00 \\
\hline \multirow{2}{*}{ Threat } & $\begin{array}{l}\text { The influx of immigrants to the area and settlement in } \\
\text { poor-quality buildings, maintaining these buildings and } \\
\text { preventing texture to be modifid }\end{array}$ & & 2.15 & 0.30 \\
& & &
\end{tabular}


The risk of destruction of orchards and farmland and 0.15

1.00

0.15 natural landscapes

Thus, according to Figure..... priority strategies in framework field should be often aggressive strategies

\begin{tabular}{|l|l|l|}
\hline Conservative & & Offensive \\
\hline & & \\
\hline Defensive & Competitive & \\
\hline
\end{tabular}

Table 11. The evaluation of internal factors in management field

\begin{tabular}{|c|c|c|c|c|}
\hline \multicolumn{2}{|c|}{ Internal factors } & \multirow{2}{*}{$\begin{array}{l}\text { Normalized } \\
\text { Coefficient }\end{array}$} & \multirow{2}{*}{$\begin{array}{l}\text { Score } \\
4\end{array}$} & \multirow{2}{*}{$\begin{array}{l}\text { Weighted } \\
\text { Score } \\
0.64\end{array}$} \\
\hline Strengths & setting councils in all neighborhoods & & & \\
\hline & All communities have their own religious sites & 0.10 & 4 & 0.40 \\
\hline & $\begin{array}{l}\text { providing the possibility of women's activities } \\
\text { through concils }\end{array}$ & 0.10 & 4 & 0.40 \\
\hline & $\begin{array}{l}\text { Paying attention of Urban infrastructure managers } \\
\text { to passages of proposals }\end{array}$ & 0.15 & 4 & 0.60 \\
\hline & Rey is a slum-free city & 0.12 & 3 & 0.36 \\
\hline \multirow[t]{4}{*}{ Weaknesses } & begging and retail jobs are plentiful & 0.10 & 2 & 0.20 \\
\hline & $\begin{array}{l}\text { Participation of women in neighborhood decision is } \\
\text { poor }\end{array}$ & 0.10 & 2 & 0.20 \\
\hline & $\begin{array}{l}\text { Lack of public open spaces for public activities in } \\
\text { Aminabad quarter }\end{array}$ & 0.09 & 2 & 0.18 \\
\hline & $\begin{array}{l}\text { The number of public transport in terms of most } \\
\text { residents is not enough }\end{array}$ & 0.08 & 2 & 0.16 \\
\hline Total & & 1.00 & & 3.14 \\
\hline
\end{tabular}

Table 12. Assessment of external factors in management field

\begin{tabular}{|c|c|c|c|c|}
\hline & External factors & $\begin{array}{l}\text { Normalized } \\
\text { Coefficient }\end{array}$ & Score & $\begin{array}{l}\text { Weighted } \\
\text { Score }\end{array}$ \\
\hline \multirow[t]{3}{*}{ Opportunity } & $\begin{array}{l}\text { Implementation of city development strategic plan } \\
\text { to reduce poverty in the city }\end{array}$ & 0.25 & 4.00 & 1.00 \\
\hline & $\begin{array}{l}\text { Taking advantage of public participation in urban } \\
\text { development plan }\end{array}$ & 0.20 & 3.00 & 0.60 \\
\hline & $\begin{array}{l}\text { Taking advantage of public spaces to perform } \\
\text { certain rituals }\end{array}$ & 0.25 & 4.00 & 1.00 \\
\hline \multirow[t]{3}{*}{ Threat } & $\begin{array}{l}\text { irregular migration of Afqans and identity } \\
\text { problems in the texture }\end{array}$ & 0.15 & 2.00 & 0.30 \\
\hline & $\begin{array}{l}\text { Increasing the possibility of unauthorized } \\
\text { construction }\end{array}$ & 0.15 & 2.00 & 0.30 \\
\hline & Total & 1.00 & & 3.20 \\
\hline
\end{tabular}

Thus, according to Figure..... priority strategies in management field should be often aggressive strategies

\begin{tabular}{|l|l|l|}
\hline Conservative & & Offensive \\
\hline & & \\
\hline Defensive & Competitive & \\
\hline
\end{tabular}

Table 13. Respondents evaluated using a significance level in the study area by Chi-square test from the view of citizens and managers 


\begin{tabular}{|c|c|c|}
\hline Index & $\begin{array}{l}\text { The average rating in the } \\
\text { studied area }\end{array}$ & $\begin{array}{l}\text { Considerable } \\
\text { level }\end{array}$ \\
\hline Beautification of the city & 4 & \\
\hline $\begin{array}{l}\text { Use of material (material) suitable for urban furniture, } \\
\text { equipment and facilities }\end{array}$ & 3.7 & \\
\hline marginalized urban informal settlements & 4 & \\
\hline Dark passages and under the bridges & 4.1 & 0.000 \\
\hline Improvement of urban living standards in all areas & 4 & 0.000 \\
\hline $\begin{array}{l}\text { Aesthetic urban space, the physical aspects of space, volume } \\
\text { and type of their composition }\end{array}$ & 3.7 & 0.000 \\
\hline Color staining of belonging and unity & 3.9 & 0.000 \\
\hline Sensory richness & 3.8 & 0.000 \\
\hline Low quality of applications, services and municipal structures & 3.9 & 0.000 \\
\hline $\begin{array}{l}\text { Creating favorable spaces in the city for the discharge of } \\
\text { emotional teenagers and young adults }\end{array}$ & 4 & 0.000 \\
\hline Streets and squares geometric problems & 3.8 & 0.000 \\
\hline Unauthorized access roads to the highway & 3.9 & 0.000 \\
\hline high-rise buildings and dilapidated and abandoned buildings & 4 & \\
\hline $\begin{array}{l}\text { creating the perfect view, open spaces, and correct urban } \\
\text { furniture }\end{array}$ & 4.4 & \\
\hline The lack of identity and intimacy in urban areas & 4.4 & \\
\hline Lack of attachment to the urban environment... & 3.8 & \\
\hline
\end{tabular}

**) Average rating (rating 1: very low, Rank 2: low, Rank 3: Moderate, Rank 4: High and Rank 5: very much)

*) Considerable at level 99

Source: Calculations based on data collected from questionnaires

Table 14. Significant level of respondents evaluate appropriate strategies for efficient management system in the field of design and urban landscape to reduce the rate vandalistic behavior in the studied area using the Chi-square test

\begin{tabular}{lcc}
\hline \multicolumn{1}{c}{ Index } & $\begin{array}{c}\text { The average rating in } \\
\text { the studied area }\end{array}$ & $\begin{array}{c}\text { Considerable } \\
\text { level }\end{array}$ \\
\hline $\begin{array}{l}\text { Change the attitude of citizens to public property and facilities in } \\
\text { order to maintain them }\end{array}$ & 4.2 & $0.000^{*}$ \\
\hline $\begin{array}{l}\text { Consideration beautification principles in city in various aspects of its } \\
\text { constituent spaces such as buildings, streets, green spaces and ... }\end{array}$ & 4.1 & $0.000^{*}$ \\
\hline $\begin{array}{l}\text { Management planning for designing and locating equipment and } \\
\text { facilities }\end{array}$ & 4.4 & $0.001^{*}$ \\
\hline $\begin{array}{l}\text { Create background for public participation in community issues by } \\
\text { providing correlation between the officials and the people }\end{array}$ & 4 & $0.001^{*}$ \\
\hline $\begin{array}{l}\text { The use of appropriate materials in urban furniture, equipment and } \\
\text { facilities that be destroyed more }\end{array}$ & 3.8 & $0.000^{*}$ \\
\hline Enhance the quality of programs, services and urban constructions & 4.2 & $0.000^{*}$ \\
\hline $\begin{array}{l}\text { Enactment of appropriate legislation for social supply and the support } \\
\text { of vulnerable people }\end{array}$ & 4.4 & $0.001^{*}$ \\
\hline Quality of urban design & & \\
\hline The design and location of suitable equipment and facilities & 3.78 & $0.000^{*}$ \\
\hline Create balance and regional harmony & 4.12 & $0.000^{*}$ \\
\hline Reducing social inequalities & 3.36 & $0.000^{*}$ \\
\hline
\end{tabular}




\begin{tabular}{lll}
\hline Balanced development of urban & 3.33 & $0.000^{*}$ \\
\hline Coordination between existing institutions and organization & 4.71 & $0.000^{*}$ \\
\hline Taking advantage of local managers & 4.13 & $0.000^{*}$ \\
\hline To make people aware & 3.8 & $0.000^{*}$ \\
\hline $\begin{array}{l}\text { Improve urban living standards in all areas and neighborhoods } \\
\text { particularly in deprived areas and neighborhoods }\end{array}$ & 4.2 & $0.000^{*}$ \\
\hline $\begin{array}{l}\text { Establish public trust and confidence to the urban management } \\
\text { activities }\end{array}$ & 4.1 & $0.000^{*}$ \\
\hline $\begin{array}{l}\text { Make favorable spaces in the city to drain the excitement of youth and } \\
\text { young adults }\end{array}$ & 3.8 & $0.000^{*}$ \\
\hline Attention to aesthetics of in property and construction of facilities & & \\
\hline Design appropriate openings and balconies in residential buildings & 4.2 & $0.000^{*}$ \\
\hline Building layout relative to each other & 4.1 & $0.000^{*}$ \\
\hline Repair and maintenance of urban equipment & 3.8 & $0.000^{*}$ \\
\hline City Lights & 3.9 & $0.000^{*}$ \\
\hline Remove high-risk areas in the city & 4.1 & $0.000^{*}$ \\
\hline design parking that that be monitoring and controllable & 4.3 & $0.000^{*}$ \\
\hline Remove and organizing empty spaces in the city & 3.7 & $0.000^{*}$ \\
\hline Improving planning of space & 3.9 & $0.000^{*}$ \\
\hline Improve the restoration and maintenance of buildings & 4.2 & $0.000^{*}$ \\
\hline $\begin{array}{l}\text { Suitable locating of various activities next to each other } \\
\text { in city }\end{array}$ & 3.5 & $0.000^{*}$ \\
\hline $\begin{array}{l}\text { Proper design and implementation of adequate urban furniture } \\
\text { with environment }\end{array}$ & 3.4 & $0.000^{*}$ \\
\hline Organizing Damaged Area & 4.4 & $0.000^{*}$ \\
\hline $\begin{array}{l}\text { Promote a sense of place and promote a sense of belonging in people } \\
\text { to the place }\end{array}$ & 4.5 & $0.000^{*}$ \\
\hline Improve the quality of public spaces & 4.7 & $0.000^{*}$ \\
\hline & & \\
\hline & & $0.000^{*}$ \\
\hline
\end{tabular}

**) Average rating (rating 1: very low, Rank 2: low, Rank 3: Moderate, Rank 4: High and Rank 5: very much)

*) Considerable at level 99

Source: Calculations based on data collected from questionnaires

\section{Conclusion and Proposed Management Model}

According to the study's results ,they're familiar with comments of Ian Bentley and his colleagues, Jane Jacobs, Huber, fairness - Control Fisher and Baron, Janleng, David Chapman and anomie theory of family. In general, urban management should be coupled with proper planning and proper management in order to develop the area and to reduce vandalism. The sustainability of development in the region leads to the balance of the city in all aspects of economic, social and cultural fields. Therefore due to the facilities, capabilities, urban potential in this area and by applying strategic planning based on these factors and in the shadow of integrated management, achieve sustainable development in order to reduce the effects of destruction in the region. It also seems to be the best kind of theory about urban management in the region, is modern theory or a systematic theory. Reports and studies about vandalism

often have proposed solutions based on their findings to intervene in the matter that can be mentioned strategies in them, generally categorized in four areas

\section{Strategies to Reduce the Effects of Vandalism}

1- Prevention strategies: Which will be classified into two groups 
a) Human solutions: Related to education, awareness and creation of commitment in children and adolescents, Consulting in the field that children (or teenagers) experience violence at home or in educational environments, Parental education, Education in schools

b) Technical and legal solutions: The use of appropriate materials in urban furniture, equipment and facilities that be destroyed more, Accessibility kind of these facilities

2- Damage reduction strategies: which refers to conduct some vandalistic activities to the cultural and artistic constructive measures, providing the way for energy-draining people especially for susceptible age groups in various sports and cultural events, using materials that reduce the vulnerability of equipment

3- Rehabilitation strategies: Again in two parts of human rehabilitation and reconstruction of damaged property is separable. In reconstruction of damaged property, experiences such as the use of alternative penalties and restorative punishments for vandals (including cash and non-cash). In human rehabilitation, psychological counseling, rehabilitation period, anger management training and ... is mentioned.

4- Control Strategies: in both formal and informal controls is separable. Subject to strict official controls laid down rules. Using armed forces and the police to control and deal with the vandals, particularly in sport environments, Increase control equipment such as cameras and sensors in sport and education environments, urban furniture and so on. In contrast informal controls control by families, the same age groups, schools, clubs, fans in stadiums and totally, emphasized on culture and social measures.

Also, in the most sources, been emphasized to the two important steps: strengthen knowledge and specialization in face to the issue.

The first step: Strengthening vandalism knowledge is known as a small crime which can be a background to bigger crimes and from this point of view, dealing with is a significant need for the development of society and neglecting it will leave irreparable effects. A serious obstacle for the deal with this phenomenon, weak statistics and researches in this field. Plan to reduce vandalism we need to know the criteria such as size, intensity, amplitude, frequency and diversity of sabotage. And that destruction has taken place in what areas (health, leisure, environment, services, education, sports, etc.) One of the few comprehensive studies in this area was Mr. Mohseni (1374) in the metropolitan area of Tehran that was done by the municipality and the Institute for Social Studies and Research of Tehran University. Other research is limited, inconsiderable and periodic. In short, the phenomenon is not known; deal with it would be meaningless. Reduce the problem of vandalism in case of complete identification needs the firm determination of authorities and macro decision-makers of community and activity and appropriate intervention of cultural, technological, educational, educative and welfare functions. Given the priority strategies identified and presented on various aspects as well as chi-square test variables, we can be proposed a management model in " $20^{\text {th }}$ District" in order to deal with urban vandalism. In this model attention to designing and policy in various aspects is considered. Also monitoring and planning should not be limited to the initial phase and policies but should be considered in the design, implementation and maintenance of urban spaces, urban furniture, etc. and in this respect also to be noted. On this basis, and considering the explanations of urban management requirements mentioned in the theoretical foundations. Range of measures in urban management in the issue of vandalism in this study, divided into three-level structure.

Before execution: Including policy and planning

Execution: Including locating and installing street furniture and other design elements environment

Maintenance: the preservation and restoration of urban furniture, urban spaces and removal design defects and failure. The strategies presented in social, economic, framework and management classified in three steps.

Table 15. Strategies provided in various aspects: Social, Economic, Framework and Management

\begin{tabular}{cccc}
\hline Aspects & \multicolumn{1}{c}{ Before execution } & \multicolumn{1}{c}{ Execution } & \multicolumn{1}{c}{ After Execution } \\
Social & - Use the views of the people in \\
& the projects & $\begin{array}{l}\text { Cultural and publicity measures } \\
\text { during the implementation of the plan }\end{array}$ & $\begin{array}{l}\text { Increase prosperity by } \\
\text { design spaces by } \\
\text { cultural activities }\end{array}$ \\
\hline
\end{tabular}


participation of civil society at this stage

- Cultural activities and education to people familiar with the plan project in schools

- Promote a sense of place and promote a sense of belonging of people to the place
- Public oversight and additional care of responsible organizations in reducing the phenomenon of vandalism

\begin{tabular}{|c|c|c|c|}
\hline $\begin{array}{c}\text { Economi } \\
\mathrm{c}\end{array}$ & $\begin{array}{l}\text { Pathology to provide youth } \\
\text { employment within the scope of } \\
\text { their employment plan } \\
\text { Self-supporting public institutions } \\
\text { - Strengthening the role of public } \\
\text { institutions such as Wise Young } \\
\text { Benefactors, Tafa and ... The } \\
\text { proposed investment in service } \\
\text { projects in neighborhoods }\end{array}$ & & \\
\hline $\begin{array}{c}\text { Framew } \\
\text { ork }\end{array}$ & $\begin{array}{l}\text { Design and create urban spaces } \\
\text { that lead to citizens' presence } \\
\text { and current activities } \\
\text { - Observance of beautify } \\
\text { principles } \\
\text { in the city in various aspects of } \\
\text { its constituent spaces such as } \\
\text { buildings, streets, green spaces } \\
\text { and ... }\end{array}$ & $\begin{array}{l}\text { - Attractive and artistic design of } \\
\text { urban furniture } \\
\text { - Principles relating to the factors } \\
\text { influencing social solidarity and a } \\
\text { sense of belonging to the residential } \\
\text { environment } \\
\text { - Observance special standards in } \\
\text { construction and peripheral face } \\
\text { - The build quality and coordination } \\
\text { of the urban equipment } \\
\text { with place that } \\
\text { have been located }\end{array}$ & $\begin{array}{l}\text { Timely repair of } \\
\text { damaged furniture } \\
\text { Providing urban spaces } \\
\text { lighting and resolve } \\
\text { difficulties in this field }\end{array}$ \\
\hline $\begin{array}{c}\text { Manage } \\
\text { ment }\end{array}$ & $\begin{array}{l}\text { - Creating a comprehensive } \\
\text { scheme of social supply and } \\
\text { public benefit } \\
\text { - Enactment of appropriate } \\
\text { legislation social supply and the } \\
\text { support of vulnerable people } \\
\text { - Provide a textbook of education, } \\
\text { training and science for schools } \\
\text { with the aim of deterrent } \\
\text { barriers against the rush of } \\
\text { deviance and vandalism } \\
\text { - Presentation the necessary } \\
\text { training to different groups } \\
\text { urbanite }\end{array}$ & $\begin{array}{l}\text { - Planning to motivate and public } \\
\text { participation } \\
\text { in urban activities } \\
\text { Develop cultural facilities and create } \\
\text { social trust }\end{array}$ & $\begin{array}{l}\text { Found a committee to } \\
\text { monitoring of urban } \\
\text { furniture and urban } \\
\text { furniture required } \\
\text { report for restoration }\end{array}$ \\
\hline
\end{tabular}

\section{References}

Abdullah, K. A. (2007). Explanation the issue of vandalism and coping with it. Amniat Quarterly, 1.

Abdullah, P. I. (2005). Brief in relation to urban culture, vandalism, urban insecurity and crime. Mazandaran University Roozbahan. Monthly municipalities, 25 and 28

Asayesh, H., \& Moshiri, S. R. (2002). The methodology and techniques of scientific research in the humanities, with emphasis on geography. Ghomes Publishing.

Hafeznia, M. R. (2005). Introduction to Research Methods in Human Sciences, Tehran, Samt publishing

Mohseni, T. A. (1988). The theoretical and empirical vandalism, a social sciences, 16.

Mohseni, T. A. (1991). Alienation, social science letter, 2(2). Published by Tehran University, Tehran.

Mohseni, T. A. (1993). Suicide in Ilam, Social Studies and Research Institute of Tehran University, Tehran. 
Mohseni, T. A. (1995). Investigate the causes of vandalism in Tehran and ways to prevent and treat it. Center for Cultural Studies and Social Research of Tehran, Tehran Municipality

Mohseni, T. A. (1997). Investigate the causes of unrest and discontent in the industrial environment and labor of the country. Political - Police Department, Interior Ministry.

Mohseni, T. A. (2006). Vandalism; Principles of Social Psychology, Sociology and behavioral psychology Vandalistic in the discussion of pathology and social deviance. Aan publication, Tehran.

Pakzad, J. (2007). Essays on urban design, planning and design book series, Tehran. Shahidi publishing

Shekarbeygi, A., \& Mohammadi, R. F. (2007). Review possible causes of vandalism among young people, rammers and on the findings of a study in Tehran. Detailed design of $20^{\text {th }}$ District in Tehran.

Statistical Center of Iran. (2006). General Census of Population and Housing in Tehran.

Statistical Center of Iran. (2011). General Census of Population and Housing in Tehran.

Tavassoly, M., \& Bonyadi, N. (2007). Urban design, urban spaces and their status in life and urban landscape, Tehran, Shahidi publishing: Iran Center of Urban and Architecture Studies.

Zekavat, K. (2006). Need for urban design in the process of preparing the master plan, Sofeh publication, No 30, scientific and research publication of Urban \& Architecture, Faculty of Architecture \& Urban, Shahid Beheshti University.

\section{Copyrights}

Copyright for this article is retained by the author(s), with first publication rights granted to the journal.

This is an open-access article distributed under the terms and conditions of the Creative Commons Attribution license (http://creativecommons.org/licenses/by/3.0/). 